\title{
The Impact of Specialized Accreditation on Program Quality: Aviation Students' Perspectives
}

\author{
Jeanne A. Radigan \\ Farmingdale State College
}

Author Note: This paper was adopted from: Radigan, J.A. (2011). Student perceptions of quality in collegiate aviation: A comparative analysis of accredited and non-accredited institutions. (Doctoral dissertation). Publication pending.

\begin{abstract}
Quality assurance of academic programs has traditionally been through accreditation. Specialized accreditation is a means for specific academic fields to ensure quality. In the field of aviation, the Aviation Accreditation Board International (AABI) is the sole accrediting agency for collegiate aviation programs. Currently 25 percent of the institutions that offer four year non-engineering aviation degrees have one or more of their programs accredited by AABI. The purpose of this study was to examine if students' perceptions of quality differ between accredited and non-accredited programs using the quality dimensions of curriculum, faculty, environment, facilities and equipment, student outcomes and overall satisfaction.

Students currently enrolled in four year aviation degree programs from 22 institutions participated in the study. The findings indicated that significant differences in students' perceptions of quality exist in favor of accredited programs for curriculum, and facilities and equipment, as well as for several measures of faculty quality. Additionally, students in accredited programs perceived that their degree was preparing them well for their intended career to a significantly greater extent than students in non-accredited programs. Results of this study have implications for administrators and faculty seeking to improve the quality of their programs.
\end{abstract}

\section{INTRODUCTION}

Today the aviation industry faces unprecedented challenges. Airways are overcrowded and are being managed by antiquated systems, airports are faced with increasing delays, security threats pose real risks to the travelling public and the global economy, and training standards for our nation's pilots are under scrutiny. The industry is dependent upon having highly qualified, properly trained individuals admitted into the various sectors of this industry.

Collegiate aviation programs are a vital resource for providing the industry with competent personnel. Collegiate programs, however, can vary considerably on the level of standards they adhere to and on how they are administered. Quality of programs can vary considerably from institution to institution, even when required to meet minimum FAA standards as is the case for programs involving flight training or the licensing of aircraft mechanics. The Council on Aviation Accreditation (CAA), an offshoot of the University Aviation Association, was established in 1988 to assure program quality to various stakeholders, namely the educational community and the public they serve. Does specialized accreditation impact the quality of programs? Do levels of student satisfaction in accredited and non-accredited programs differ? All institutions, regardless of their accreditation status or accreditation intentions, can benefit from having a better understanding of student perceptions of quality. Maintaining a satisfied student body is a key element in the viability of any academic program. 


\section{RELATED LITERATURE}

\section{Defining Quality in Higher Education}

Defining quality in higher education is an evolving task and is largely dependent upon whose perspective is being discussed (Alstete, 2004; Harvey \& Green, 1993; Nordvall \& Braxton, 1996; Van Kemenade, Pupius, \& Hardjono, 2008). Quality can be viewed as an absolute, similar in nature to beauty and truth (Sallis \& Hingley, 1991) or in terms of thresholds that must be attained to be labeled quality. Another view of quality relates the processes to the outcomes, rather than to an absolute threshold (Harvey \& Green, 1993).

In 1993, Harvey and Green grouped the widely varying conceptualizations of quality into five distinct, yet interrelated categories as follows: (1) exception, which relied on the traditional view of exclusiveness even though it offered no benchmarks in defining quality. It relied more on the notion that quality was instinctively known when it was encountered; (2) perfection, which related quality to consistency of performance. This moved away from the exclusiveness theory of quality and made it obtainable to those able to conform to, and maintain specific standards; (3) fitness for purpose, more of a functional definition of quality, which measured how well the end product or service, met the intended purpose of the users; (4) value for money; and (5) transformative or "value added" concept. Much attention has been given to this last conceptualization category which argues that both input and output data must be analyzed over time to gain a sense of what was gained by completing a particular program of study. For example, if only the best and brightest students are recruited into a program, one would expect high levels of achievement and outcomes at the program's completion. Caution must be exercised in assuming excellence merely for having recruited bright students (Astin, 1995). This transformative concept of quality has been widely accepted as a true indicator of quality in higher education (Astin, 1985, 1993, 1995; Nightengale \& O’Neill, 1994) and has led to an emphasis on outcomes by accrediting bodies in recent years.

Although "quality" of a program can mean many different things to different people, the elements of curriculum, faculty, facilities, finances and students are common elements given in defining program quality (Alstete, 2004; Harvey \& Green, 1993; Van Kemenade, et. al, 2008). These factors alone however, do not assure high quality. Outcome variables and the environment of the program need to be considered when analyzing quality. The impact of a program's environment on learning has been recognized by many (Astin, 1985, 1993; Nightingale \& O’Neill, 1994; Sergiovanni, 1994) yet is often neglected due to the difficulty in assessing it (Astin, 1993). The importance of the learning environment and student outcomes in determining quality is evidenced by the shift of accrediting agencies from input criteria to process (environment) and outcomes assessments (Prather, 2007).

\section{Defining Quality in Collegiate Aviation Programs}

The University of Illinois Institute of Aviation surveyed graduates of their program for the period 1950 - 1978. Results of this study shed some light on what the quality indices of aviation programs were from an alumni perspective and included curriculum, facilities and equipment, and industry placement services (Johnson \& Sredl, 1979). Fifteen years later, Kuhns (1994) set out to establish a quality norm for collegiate aviation programs by surveying program chairs on their perceptions of what constituted key quality factors for aviation programs. In this study, faculty, facilities and equipment, curriculum, internships and financial resources were all identified as important determinants of program quality.

Lindseth (1996) recognized the need to identify quality indicators for collegiate aviation programs, particularly those programs that had flight training as a component. He developed a model of quality for collegiate aviation programs by surveying "experts" in the field, which consisted of baccalaureate 
aviation program administrators and directors of flight training from U.S. based airlines. The model that was developed based on this research included ten quality indices: curriculum, students, faculty, program activities, equipment, facilities, leadership, resources, reputation and value. Using regression analysis, curriculum and faculty were both found to be predictors of program quality. These ten quality indices were further validated by Hankins (2007) who surveyed aviation educators and industry representatives.

\section{Accreditation}

As the system of institutions of higher education was developing in the United States, it became apparent that some form of standardization among institutions was necessary. Variations in standards and degree requirements were making credit transfers and admittance into graduate programs a difficult task. This resulted in a movement to establish minimum standards in the year 1890 (Alstete, 2004).

Today accreditation remains the primary means of assuring program quality to students and the public (Alstete, 2004; Eaton, 2009). In the United States, institutions of higher education operate with considerable autonomy and independence unlike some other countries that exist under a centralized authority such as a Federal Ministry of Education. Both the federal and state governments in this country consider accreditation to be a reliable indicator of quality and although voluntary, limit government sponsored financial aid to institutions that are accredited (Eaton, 2009).

\section{Specialized Accreditation}

Specialized accreditation is a means of assuring quality for specific academic programs. Programs seeking specialized accreditation are typically required to be part of a regionally or nationally accredited program and thus lend additional prestige to the program (Prather, 2007). However, specialized accreditation can be viewed as redundant. Costs associated with the specialized accreditation process can be excessive and the time and energy commitment required of the faculty and staff is often overwhelming (Litwack, 1986). Many programs considering specialized accreditation claim that they are not able to meet the accreditation criteria, particularly curricula standards. Many programs stated they were under no pressure from stakeholders to seek specialized accreditation and that their alumni have proven to be successful without it (Prather, 2007).

\section{Aviation Accreditation Board International}

The Aviation Accreditation Board International (AABI) is the sole specialized accrediting body for collegiate aviation programs and is a nonprofit, nongovernmental agency whose members include educators, industry representatives and regulators. AABI is an offshoot of the University Aviation Association (UAA), a non-profit organization that was founded in 1947 to serve the needs of the aviation educational community. A survey conducted by the UAA revealed a general consensus for the need of a specialized accrediting agency for aviation degree programs. In October, 1988, the UAA established the Council on Aviation Accreditation (CAA) as an autonomous, legally charted entity (UAA, n.d.). By 1992, the CAA had accredited eight programs at four schools (Lindseth, 1996). Today the scope has expanded to include international programs. In 2006, the CAA officially adopted the name Aviation Accreditation Board International to better reflect this aim and to avoid possible confusion with the Civil Aeronautics Authority abroad.

There are 103 institutions offering four year non-engineering aviation degrees in this country. Approximately one fourth of these institutions have a program that is accredited by AABI (AOPA, 2009). A 2007 study set out to determine why such a small percentage of the institutions were accredited. Program administrators, aviation students and industry employers were surveyed to measure their perception of the value of AABI accreditation (Prather, 2007). 
Administrators of accredited programs cited prestige, standardization and ability to attract quality faculty as the benefits of accreditation. The reasons for not seeking accreditation given by non-accredited program administrators were most often centered on a cost/benefit analysis. The costs in terms of the financial resources and faculty man-hours needed to complete the required self study were perceived to be greater that the returned benefits. Many institutions viewed the specialized accreditation process as redundant with their institutions regional accreditation. Students were found to have little awareness of the existence of $A A B I$ and reported that $A A B I$ accreditation did not influence their decision to enroll in a particular program. Industry employers were also found to lack AABI awareness, contradicting previous assumptions held by AABI and academics that graduates of accredited programs were preferred by industry (Prather, 2007).

\section{PURPOSE OF THE STUDY}

The purpose of this study was to determine if students' perceptions of collegiate aviation program quality differed between AABI accredited and non-accredited four year degree programs. Quality was defined by the dimensions of curriculum, faculty, environment, facilities and equipment, student outcomes and overall satisfaction.

\section{METHODOLOGY}

\section{Subjects}

Students currently enrolled in four year, non-engineering aviation degree programs across the United States were invited to participate in this study. Students between the ages of 18 and 64 years were approved by the Internal Review Board process to participate in this study.

\section{Survey Instrument}

A survey was developed to measure student perceptions of quality based on a thorough review of past research efforts involved in defining quality of collegiate programs. Due to the limited publications specific to the field of aviation, the literature review included past research efforts across several disciplines. Part one consisted of ten demographic questions for analysis purposes and part two measured the quality dimensions of curriculum, faculty, environment, facilities and equipment, student outcomes, and student level of satisfaction with their degree program. Students were asked to report their level of agreement on 50 items using a five point Likert scale (see Appendix A). To ensure content validity, the survey was juried by a five member committee consisting of three faculty members from AABI accredited programs and two from non-accredited programs. To determine the reliability of the instrument, Cronbach's alpha coefficients of internal consistency were calculated for each variable and ranged from .66 - .88. According to George and Mallory (2003) acceptable Chronbach alpha coefficients for social science research studies can be defined as follows: greater than .9 - excellent; greater than .8 good; greater than .7 - acceptable; greater than .6 - questionable; greater than .5 - poor; less than .5 unacceptable. The scale reliability for each variable is given below in Table 1. 
Table 1. Scale Reliabilities

\begin{tabular}{llcl}
\hline Variables & Items & $\begin{array}{c}\text { Range of } \\
\text { Scores }\end{array}$ & $\begin{array}{l}\text { Alpha } \\
\text { Coefficient }\end{array}$ \\
\hline Curriculum & 2, 11, 14, 25, 32, 38, 45r & $7-35$ & 0.66 \\
Faculty & 6, 13, 15, 19, 22, 26, 34r, 40r, 42, 44 & $10-50$ & 0.86 \\
Environment & 1, 3, 7, 21r, 27, 35, 37r, 39, 43, 46 & $10-45$ & 0.77 \\
Facilities and & 5, 10, 12, 18, 31, 49,50 & $7-35$ & 0.76 \\
Equipment & 4, 9,17, 23r, 28, 30, 36, 41, 47 & $9-45$ & 0.83 \\
Student Outcomes & $6-30$ & 0.88 \\
\hline Level of Satisfaction & 8, 16, 24, 29, 33, 48 & 6 & \\
\hline
\end{tabular}

An ' $r$ ' denotes item reversal for statistical purposes

\section{Data collection}

An electronic version of the survey was developed and distributed to aviation faculty members soliciting their help in making the survey available to students. Faculty members attending the AABI annual conference in July, 2010 and faculty members listed on the UAA's website were targeted for assistance. Additionally, faculty members attending the UAA's annual conference in October, 2010 were asked if they would be willing to distribute the survey either electronically or in hard copy to their students. Copies of the survey, along with self-addressed stamped envelopes were provided to faculty agreeing to assist in this way. The electronic link was active mid-September through November 1, 2010, resulting in 267 electronic submissions. An additional 282 paper surveys were returned in the mail.

\section{DATA ANALYSIS AND FINDINGS}

\section{Demographics}

A total of 549 surveys were returned from 22 institutions representing the five geographic regions of the United States, yielding 510 survey submissions valid for analysis. Table 2 illustrates the demographics of the participants in regards to geographic location of the institution.

Table 2. Demographics of the Participants (geographic location of institution) $(N=510)$

\begin{tabular}{ccrrr}
\hline & & & $\begin{array}{r}\text { Valid } \\
\text { Percent }\end{array}$ & $\begin{array}{r}\text { Cumulative } \\
\text { Percent }\end{array}$ \\
\hline Location & 32 & 6.27 & 6.30 & 6.30 \\
Northeast & 138 & 27.06 & 27.17 & 33.46 \\
Southeast & 245 & 48.04 & 48.23 & 81.69 \\
Midwest & 73 & 14.31 & 14.37 & 96.06 \\
Southeast & 20 & 3.92 & 3.94 & 100.00 \\
West & 508 & 99.61 & 100.00 & \\
Total & 2 & .39 & & \\
Missing & 510 & 100.00 & & \\
\hline Total & & &
\end{tabular}


The geographic regions were adopted from the online resource "Thinkquest Library for this study and are defined as follows (United States Regions, 1998):

- Northeast: Connecticut, Delaware, Maine Massachusetts, Maryland, New Hampshire, New Jersey, New York, Pennsylvania, Rhode Island, Vermont and Washington D.C.

- Southeast: Alabama, Arkansas, Florida, Georgia, Kentucky, Louisiana, Mississippi, North Carolina, South Carolina, Tennessee, Virginia and West Virginia.

- Midwest: Illinois, Indiana, Iowa, Kansas, Michigan, Minnesota, Missouri, Nebraska, North Dakota, Ohio, South Dakota and Wisconsin.

- Southwest: Arizona, New Mexico, Oklahoma and Texas

- West: Alaska, California, Colorado, Hawaii, Idaho, Montana, Nevada, Oregon, Utah, Washington and Wyoming.

Table 3 illustrates the demographics of the participants regarding the accreditation status of their program and their major course of study.

Table 3. Demographics of the Participants (accreditation status and major course of study) $(N=510)$

\begin{tabular}{ccrrr}
\hline & & & Valid & $\begin{array}{r}\text { Cumulative } \\
\text { Percent }\end{array}$ \\
& Respondents & Percent & Percent & 68.66 \\
Accredited Status & & & & \\
Accredited & 344 & 67.45 & 68.66 & \\
non-accred & 157 & 30.78 & 31.34 & 100.00 \\
Total & 501 & 98.24 & 100.00 & \\
Missing & 9 & 1.76 & & \\
Total & 510 & 100.00 & & \\
\hline Major & & & & \\
prof. pilot/flight edu & 277 & 54.31 & 55.62 & 55.62 \\
aviation adm/mgmt & 132 & 25.88 & 26.51 & 82.13 \\
aviation studies & 46 & 9.02 & 9.24 & 91.37 \\
Air Traffic Control & 38 & 7.45 & 7.63 & 99.00 \\
aviation maintenance & 5 & .98 & 1.00 & 100.00 \\
Total & 498 & 97.65 & 100.00 & \\
Missing & 12 & 2.35 & & \\
\hline Total & 510 & 100.00 & & \\
\hline
\end{tabular}

As depicted in Table 3, approximately two thirds of the respondents were enrolled in an AABI accredited program and over one half of the respondents were enrolled in programs focused on pilot training. Further analysis of the respondents' demographics by class level, GPA and gender is given in Table 4. 
Table 4. Demographics of the Respondents (class level, GPA and gender) $(N=510)$

\begin{tabular}{ccrrr}
\hline & & & Valid & $\begin{array}{r}\text { Cumulative } \\
\text { Percent }\end{array}$ \\
\hline Class Level & Respondents & Percent & Percent & \\
Freshman & 91 & 17.84 & 17.98 & 17.98 \\
Sophomore & 94 & 18.43 & 18.58 & 36.56 \\
Junior & 162 & 31.76 & 32.02 & 68.58 \\
Senior & 159 & 31.18 & 31.42 & 100.00 \\
Total & 506 & 99.22 & 100.00 & \\
Missing & 4 & .78 & & \\
\hline Total & 510 & 100.00 & & \\
\hline GPA & & & & \\
under 2.0 & 0 & .00 & .00 & .00 \\
$2.0-2.49$ & 25 & 4.90 & 5.07 & 5.07 \\
$2.5-2.99$ & 112 & 21.96 & 22.72 & 27.79 \\
3.0 - 3.49 & 197 & 38.63 & 39.96 & 67.75 \\
over 3.5 & 159 & 31.18 & 32.25 & 100.00 \\
Total & 493 & 96.67 & 100.00 & \\
Missing & 17 & 3.33 & & \\
\hline Total & 510 & 100.00 & & \\
\hline Gender & & & & \\
Male & 444 & 87.06 & 87.06 & 87.06 \\
Female & 66 & 12.94 & 12.94 & 100.00 \\
\hline Total & 510 & 100.00 & 100.00 & \\
\hline
\end{tabular}

Thirteen percent of the surveys were submitted by females representing a higher percentage than is found in industry. Females account for approximately six percent of the 600,000 active pilots in the United States and approximately four percent of the non-pilot aviation jobs (About WAI, 1996 - 2010).

\section{Quality Perception Analysis}

A series of independent-samples $t$ tests was conducted to analyze the means of accredited and nonaccredited institutional responses for the quality dimensions of curriculum, faculty, environment, facilities and equipment, student outcomes, and overall satisfaction. Table 5 illustrates the results of the $t$ tests for each of the variables. Results of the $t$ tests indicated that student perceptions of quality were higher in accredited programs. Students in accredited programs on average perceived the quality of their curriculum, $t(251.01)=3.68, p \leq .00$ and of their facilities and equipment, $t(497)=2.61, p=.01$, significantly higher than students in non-accredited programs. It is interesting to note that aviation educators and industry representatives have ranked the top three quality characteristics of collegiate aviation as: 1. curriculum; 2. faculty; and 3. equipment (Hankins, 2007). 
Table 5. Independent Samples t test Comparing How Students’ Perceptions of Quality Differ Based on Accreditation Status of Their Program $\left(N_{a}=344, N_{n}=157\right)$

\begin{tabular}{|c|c|c|c|c|c|c|c|}
\hline & $\begin{array}{l}\text { accreditation } \\
\text { status }\end{array}$ & $\mathrm{N}$ & $\mathrm{M}$ & SD & $t$ & $\mathrm{df}$ & $p$ \\
\hline \multirow[t]{2}{*}{ Curriculum } & accredited & 326 & 28.30 & 3.32 & \multirow[t]{2}{*}{3.68} & \multirow[t]{2}{*}{251.01} & \multirow[t]{2}{*}{.00} \\
\hline & non-accred & 151 & 26.93 & 3.97 & & & \\
\hline \multirow[t]{2}{*}{ Faculty } & accredited & 328 & 41.25 & 5.45 & \multirow[t]{2}{*}{1.59} & \multirow[t]{2}{*}{473} & \multirow[t]{2}{*}{.11} \\
\hline & non-accred & 147 & 40.35 & 6.23 & & & \\
\hline \multirow[t]{2}{*}{ Environment } & accredited & 323 & 36.80 & 5.95 & \multirow[t]{2}{*}{-.15} & \multirow[t]{2}{*}{471} & \multirow[t]{2}{*}{.88} \\
\hline & non-accred & 150 & 36.89 & 5.72 & & & \\
\hline \multirow{2}{*}{$\begin{array}{l}\text { Facilities \& } \\
\text { Equipment }\end{array}$} & accredited & 342 & 28.59 & 4.21 & \multirow[t]{2}{*}{2.61} & \multirow[t]{2}{*}{497} & \multirow[t]{2}{*}{.01} \\
\hline & non-accred & 157 & 27.51 & 4.56 & & & \\
\hline \multirow{2}{*}{$\begin{array}{l}\text { Student } \\
\text { Outcomes }\end{array}$} & accredited & 333 & 34.97 & 5.25 & \multirow[t]{2}{*}{1.74} & \multirow[t]{2}{*}{263.40} & \multirow[t]{2}{*}{.08} \\
\hline & non-accred & 154 & 33.99 & 6.05 & & & \\
\hline \multirow{2}{*}{$\begin{array}{l}\text { Level of } \\
\text { Satisfaction }\end{array}$} & accredited & 340 & 24.70 & 4.67 & \multirow[t]{2}{*}{.42} & \multirow[t]{2}{*}{493} & \multirow[t]{2}{*}{.68} \\
\hline & non-accred & 155 & 24.51 & 4.60 & & & \\
\hline
\end{tabular}

To further analyze these differences, independent-sample $t$ tests were conducted for both of these variables' items. The results for the items measuring the variable curriculum are given in Table 6.

Table 6. Independent Samples t test Comparing How Students' Perceptions of Curriculum Differ Based on the Accreditation Status of Their Program $\left(N_{a}=344, N_{n}=157\right)$

\begin{tabular}{cccccrrr}
\hline & $\begin{array}{c}\text { accreditation } \\
\text { status }\end{array}$ & $\mathrm{N}$ & $\mathrm{M}$ & $\mathrm{SD}$ & $t$ & $\mathrm{df}$ & $p$ \\
\hline $\mathrm{q} 2$ & accredited & 335 & 3.70 & 0.91 & 1.95 & 274.03 & .05 \\
& non-accred & 155 & 3.51 & 1.01 & & & \\
q11 & accredited & 343 & 4.10 & 0.77 & 3.06 & 262.16 & .00 \\
& non-accred & 157 & 3.85 & 0.91 & & & \\
q14 & accredited & 344 & 4.50 & 0.71 & 3.21 & 242.19 & .00 \\
& non-accred & 157 & 4.24 & 0.93 & & & \\
q25 & accredited & 343 & 3.99 & 0.89 & 1.75 & 273.64 & .08 \\
& non-accred & 156 & 3.83 & 0.98 & & & \\
q32 & accredited & 334 & 4.26 & 0.75 & 2.54 & 487 & .01 \\
& non-accred & 155 & 4.07 & 0.80 & & & \\
q38 & accredited & 344 & 3.87 & 0.97 & -.28 & 499 & .78 \\
& non-accred & 157 & 3.90 & 0.93 & & & \\
q45r & accredited & 341 & 3.85 & 1.01 & 2.97 & 274.72 & .00 \\
& non-accred & 155 & 3.54 & 1.11 & & & \\
\hline
\end{tabular}

$r$ denotes item reversal 
As depicted in Table 6, all of the items measuring quality of curriculum had higher mean scores in accredited programs with the exception of q38 "There is a good variety of courses outside my major available to me each term”, which reported a higher mean score by students in non-accredited programs, although the difference was not significant. Curricula criteria in particular, are often cited by programs as being too difficult to meet and is often given as the reason for not seeking specialized accreditation (Prather, 2007). The finding from this study suggests that accreditation criteria leads to higher quality curricula and should therefore be considered by all faculty and program administrators when developing and revising curricula, whether or not AABI accreditation is being sought. An analysis of the items used to measure facilities and equipment is given in Table 7.

With the exception of q50 "Aircraft are available to meet students' needs", all of the items measure facilities and equipment reported higher means scores by students in accredited programs. Items q10 "Library resources and services are adequate;" q18 "The campus facilities and grounds are well maintained;" and q49 "Aircraft are well maintained," all reported significantly higher means for the accredited programs. The majority of the items used to measure facilities and equipment were not aviation specific, but rather a measure of the overall physical condition and aesthetics of the campus and included such things as laboratory facilities, library resources, classroom space, etc., and are often a key component in student recruitment. Facilities and equipment measures did include aircraft availability and maintenance for students in programs involving flight training. How well aircraft were maintained (q49) was reported significantly higher by students in accredited programs. No difference was found on students' perception of aircraft availability (q50), which received the lowest mean score in both groups. This finding suggests that program administrators should take the necessary steps to ensure aircraft are available to meet students' flight hour requirements. Preliminary follow up on this issue indicated that collegiate aviation programs limit enrollment based on the available fleet size and that students perceived the lack of available aircraft merely because aircraft were not available for their first choice of flight times.

Table 7. Independent Samples t test Comparing How Students' Perceptions of Facilities \& Equipment Differ Based on the Accreditation Status of Their Program $\left(N_{a}=344, N_{n}=157\right)$

\begin{tabular}{rcrrrrrr}
\hline & accreditation & & & & & & \\
& status & $\mathrm{N}$ & $\mathrm{M}$ & $\mathrm{SD}$ & $t$ & $\mathrm{df}$ & $p$ \\
\hline $\mathrm{q} 5$ & accredited & 328 & 3.75 & 0.93 & 1.65 & 480 & .10 \\
& non.accred & 154 & 3.60 & 0.98 & & & \\
q10 & accredited & 343 & 4.09 & 0.88 & 2.42 & 269.42 & .02 \\
& non.accred & 157 & 3.87 & 1.00 & & & \\
q12 & accredited & 338 & 4.10 & 0.84 & .29 & 493 & .77 \\
& non.accred & 157 & 4.08 & 0.93 & & & \\
q18 & accredited & 343 & 4.26 & 0.82 & 2.99 & 498 & .00 \\
& non.accred & 157 & 4.01 & 1.00 & & & \\
q31 & accredited & 343 & 4.22 & 0.81 & .26 & 498 & .79 \\
& non.accred & 157 & 4.20 & 0.84 & & & \\
q49 & accredited & 295 & 4.42 & 0.91 & 4.44 & 419 & .00 \\
& non.accred & 126 & 3.98 & 0.95 & & & \\
q50 & accredited & 294 & 3.72 & 1.32 & -.39 & 280.40 & .70 \\
& non.accred & 126 & 3.77 & 1.10 & & & \\
\hline
\end{tabular}


The results of the $t$ tests for the variables student outcomes and faculty were approaching significance as depicted in Table 5. An item analysis of these variables was conducted to see if any significant differences existed between accredited and non-accredited programs. The analysis for the items measuring student outcomes is given in Table 8.

Students in accredited programs reported higher mean scores for nine out of the ten items measuring outcomes. Item q17 “This degree is preparing me well for my intended career," was significantly higher for students in accredited programs. Nearly 87 percent of students in accredited programs agreed or strongly agreed that their program was preparing them well for their intended career, compared with 76 percent of students in non-accredited programs. Program quality can be measured by how well the end product, i.e. outcomes, has met the intended purpose of the users (Harvey and Green, 1993). This particular finding suggests that accredited programs are of higher quality when this functional definition of quality is used. The analysis of items measuring faculty is given in Table 9.

Table 8. Independent Samples t test Comparing How Students' Perceptions of Outcomes Differ Based on the Accreditation Status of Their Program $\left(N_{a}=344, N_{n}=157\right)$

\begin{tabular}{cccccrrr}
\hline & accreditation & & & & & & \\
& status & $\mathrm{N}$ & $\mathrm{M}$ & $\mathrm{SD}$ & $t$ & $\mathrm{df}$ & .16 \\
$\mathrm{q} 4$ & accredited & 344 & 4.19 & 0.79 & 1.42 & 498 & \\
& non.accred & 156 & 4.08 & 0.86 & & & .13 \\
q9 & accredited & 340 & 3.89 & 0.86 & 1.53 & 251.34 & \\
& non.accred & 157 & 3.74 & 1.08 & & & .02 \\
q17 & accredited & 343 & 4.32 & 0.81 & 2.36 & 498 & .16 \\
& non.accred & 157 & 4.13 & 0.94 & & & \\
q23r & accredited & 342 & 3.78 & 1.03 & 1.41 & 495 & .07 \\
& non.accred & 155 & 3.64 & 1.06 & & & .25 \\
q28 & accredited & 343 & 3.57 & 1.06 & 1.80 & 497 & .96 \\
& non.accred & 156 & 3.39 & 1.06 & & & \\
q30 & accredited & 343 & 4.04 & 0.86 & 1.14 & 497 & .94 \\
& non.accred & 156 & 3.95 & 0.86 & & & \\
q36 & accredited & 342 & 3.67 & 0.93 & .05 & 497 & \\
& non.accred & 157 & 3.66 & 1.00 & & & .48 \\
q41 & accredited & 341 & 3.68 & 0.96 & -.08 & 496 & \\
& non.accred & 157 & 3.69 & 0.99 & & & \\
q47 & accredited & 341 & 3.78 & 0.92 & .71 & 496 & \\
& non.accred & 157 & 3.72 & 0.94 & & & \\
\hline
\end{tabular}

$r$ denotes item reversal

Although the overall mean score for the variable faculty was not significantly higher in accredited programs $(p=.11)$, it is interesting to note that every item reported a higher mean score by students in accredited programs and that several significant differences in the quality of faculty were found between the groups. Students in accredited programs perceived their aviation faculty members to be more scholarly and professionally competent (q6); as coming to class better prepared (q13); to be more enthusiastic about what they are teaching (q19); and to be more aware of new developments in the field (q44), compared with faculty in non-accredited programs. Students in accredited programs reported instruction in their major field as excellent (q42) significantly more than students in non-accredited programs. Faculty was listed among the top quality characteristics of collegiate aviation in Hankins (2007) research. Additionally, programs often cite benefits in faculty recruitment as one of their reasons 
for seeking specialized accreditation (Prather, 2007). This analysis of items measuring the quality of faculty supports this reasoning.

Table 9. Independent Samples t test Comparing How Students' Perceptions of Faculty Differ Based on the Accreditation Status of Their Program $\left(N_{a}=344, N_{n}=157\right)$

\begin{tabular}{|c|c|c|c|c|c|c|c|}
\hline & $\begin{array}{l}\text { accreditation } \\
\text { status }\end{array}$ & $\mathrm{N}$ & M & SD & $t$ & $\mathrm{df}$ & $p$ \\
\hline \multirow[t]{2}{*}{ q6 } & accredited & 343 & 4.39 & 0.84 & 2.30 & 254.38 & .02 \\
\hline & non.accred & 157 & 4.18 & 1.03 & & & \\
\hline \multirow[t]{2}{*}{ q13 } & accredited & 344 & 4.36 & 0.74 & 2.27 & 499 & .02 \\
\hline & non.accred & 157 & 4.19 & 0.89 & & & \\
\hline \multirow[t]{2}{*}{ q15 } & accredited & 343 & 4.38 & 0.74 & . 57 & 497 & .57 \\
\hline & non.accred & 156 & 4.33 & 0.84 & & & \\
\hline \multirow[t]{2}{*}{ q19 } & accredited & 344 & 4.39 & 0.72 & 2.28 & 499 & .02 \\
\hline & non.accred & 157 & 4.22 & 0.80 & & & \\
\hline \multirow[t]{2}{*}{ q22 } & accredited & 329 & 3.84 & 0.81 & .37 & 256.10 & .71 \\
\hline & non.accred & 152 & 3.81 & 0.95 & & & \\
\hline \multirow[t]{2}{*}{ q26 } & accredited & 344 & 3.97 & 0.79 & .58 & 266.65 & .56 \\
\hline & non.accred & 155 & 3.92 & 0.90 & & & \\
\hline \multirow[t]{2}{*}{ q34r } & accredited & 343 & 3.71 & 1.05 & .95 & 498 & .34 \\
\hline & non.accred & 157 & 3.61 & 1.09 & & & \\
\hline \multirow[t]{2}{*}{ q40r } & accredited & 340 & 3.64 & 1.00 & .32 & 493 & .75 \\
\hline & non.accred & 155 & 3.61 & 1.07 & & & \\
\hline \multirow[t]{2}{*}{ q42 } & accredited & 344 & 4.24 & 0.82 & 2.00 & 498 & .05 \\
\hline & non.accred & 156 & 4.07 & 0.93 & & & \\
\hline \multirow[t]{2}{*}{ q44 } & accredited & 343 & 4.32 & 0.79 & 2.16 & 496 & .03 \\
\hline & non.accred & 155 & 4.15 & 0.77 & & & \\
\hline
\end{tabular}

$r$ denotes item reversal

\section{IMPLICATIONS OF THE STUDY}

It is important for administrators and directors of collegiate aviation programs to sustain a satisfied student body to ensure their program's viability. This study set out to ascertain if there was a difference between students' perceptions of quality in accredited and non-accredited programs. The population sampled consisted of students aged 18 - 64 years currently enrolled in a non-engineering four year aviation degree program in the United States. Quality was defined by the dimensions of curriculum, faculty, environment, facilities and equipment, student outcomes and overall satisfaction.

The findings indicate that while students in both groups perceived the quality of their programs to be high, several significant differences were found between the two groups. Student perception of their curriculum was significantly higher for the accredited programs, suggesting that the accrediting criteria and standards may lead to higher caliber curricula. Facilities and equipment was also perceived significantly higher by students in accredited programs. Many of the items used to measure this dimension such as library resources, computer labs, campus buildings and grounds, etc. are a measure of the institution, rather than of the aviation program, and have little to do with an individual program's accreditation status. Caution should therefore be exercised before any cause (accreditation) and effect (higher quality) relationship is assumed for this particular quality dimension. However, the perception of how well aircraft were maintained was significantly higher for the accredited group and is worthy of note. 
Significant differences were also found to exist for several of the items used to measure faculty, supporting the belief that attaining specialized accreditation attracts high caliber faculty. A significant difference in students' perception of outcomes between accredited and non-accredited programs was also noted. Students in accredited programs perceived their degree program to be preparing them well for their intended degree to a greater extent than students in non-accredited programs.

The following recommendations for improving the quality of collegiate aviation programs based on this study's findings include:

1. Non-accredited programs should consider seeking AABI accreditation. Several measures of quality were significantly higher for the accredited programs.

2. If unable to seek accreditation at the present time due to lack of resources, program faculty and administrators should at least consider developing and revising their curricula based on the AABI criteria.

3. Aircraft scheduling should be monitored to ensure that aircraft are available to meet student needs as both programs reported the lowest mean score for this item under the facilities and equipment variable. 


\section{REFERENCES}

About WAI. (1996 - 2010). Retrieved November 20, 2010, from Women in Aviation:

http://www.wai.org/about.cfm

Alstete, J. (May 2004). Accreditation Matters: Achieving Academic Recognition and Renewal. ASHE Higher Education Report. San Francisco: Jossey-Bass.

AOPA Flight Training (2009, Dec). 2010 College Aviation Directory. 35-41.

Astin, A. (1985). Achieving Educational Excellence. San Francisco: Jossey-Bass.

Astin A. (1993). Assessment for excellence: The philosophy and practice of assessment and evaluation in higher education. Phoenix: Oryx Press.

Astin, A. (1995). Achieving Academic Excellence. San Francisco: Jossey-Bass.

Eaton, J. (2009). An Overview of U.S. Accreditation. Washington, DC: Council for Higher Education Accreditation.

George, D., \& Mallery, P. (2003). SPSS for Windows step by step: A simple guide and reference. 11.0 update (4th ed.). Boston: Allyn \& Bacon.

Hankins, A.S. (2007). Quality characteristics in aviation baccalaureate programs: A content analysis of collegiate publications (Doctoral dissertation, University of Nebraska, 2007). Dissertation Abstracts International, 68, (11A.), 4627. (UMI No. 3284242)

Harvey, L. \& Green, D. (1993) Defining Quality. Assessment and Evaluation in Higher Education, 18(1).

Johnson, W., \& Sredl, H. (1979) Institute of Aviation Graduate survey: 1950-1978. University of Illinois, Institute of Aviation.

Kuhns, M. (1994). Kansas aviation education: a comparison against national norms (Doctoral dissertation, Oklahoma State University, 1994). Dissertation Abstracts International, 55, (11A.), 3426. (UMI No. 9508636)

Lindseth, P. D. (1996). Identifying indicators of program quality in U.S. Baccalaureate Aviation Programs. (Doctoral dissertation, University of Michigan, 1996). Dissertation Abstracts International, 57, (3A.), 1046. (UMI No. 9624672)

Litwack, K.P. (1986). Specialized accreditation of baccalaureate nursing programs in the United States. (Doctoral dissertation, Kent State University 1986). Dissertation Abstracts International, 46, (12A.) , 4301.

Nightingale,P. \& O’Neil, M. (1994). Achieving quality learning in higher education. London: Kogan Page.

Nordvall, R. \& Braxton, J. (1996). An alternative definition of quality of undergraduate college education. The Journal of Higher Education, 67 (5), 481-496. 
Prather, C.D., (2007). Specialized accreditation in collegiate aviation: An analysis of the perceived value of specialized accreditation by the Aviation Accreditation Board International (Doctoral dissertation, University of Nebraska, 2007). Dissertation Abstracts International, 68 (11A), 4632.

Sallis, E., Hingley, P. (1991). College Quality Assurance Systems, Bristol: The Staff College, Mendip Papers, 20.

Sergiovanni, T.J., (1994) Building community in schools. San Francisco: Jossey-Bass.

University Aviation Association (n.d.) History Retrieved May 16, 2010 from http://www.uaa.aero/default.aspx?cid=TvAXqEqxL3U=

United States Regions (1998). Retrieved October 28, 2010, from Thinkquest Library: http://library.thinkquest.org/4552/

Van Kemenade, E., Pupius, M., \& Hardjono, T.W. (2008). More value to defining quality. Quality in Higher Education,14 (2), 175-185. 


\section{APPENDIX A}

\section{Survey}

(student format)

\section{Survey on students' perception of quality in their aviation program}

Institution: (please fill in the name of your school)

Major: (please fill in title of your degree program, such as

professional pilot, aviation administration, air traffic control, etc)

1. Gender: male ___ female

2. Class level: freshman sophomore junior senior

3. What is your GPA?

under 2.0

$2.0-2.49$

$2.5-2.99$

$3.0-3.49$

over 3.5

Please answer the following questions on a sliding scale of $\mathbf{1}-\mathbf{5}$ as follows:

\begin{tabular}{|ccccc|}
$\begin{array}{l}\text { Not important// } \\
\text { not satisfied }\end{array}$ & $\begin{array}{l}\text { Slightly important/ } \\
\text { slightly satisfied }\end{array}$ & $\begin{array}{l}\text { Moderately imp/ } \\
\text { moderately satisfied }\end{array}$ & $\begin{array}{l}\text { Important/ } \\
\text { satisfied }\end{array}$ & $\begin{array}{l}\text { Very important/ } \\
\text { very satisfied }\end{array}$ \\
1 & 2 & 3 & 4 & 5 \\
\hline
\end{tabular}

4. How important was the school's location in your decision to enroll?

123345

5. How important was the program's cost in your decision to enroll?

12345

6. How important was the program's reputation in your decision to enroll?

12345

7. How important are internship opportunities to you?

12345

8. How satisfied are you with internship opportunities offered at your

12345 institution? 
9. How important is the opportunity to participate in extracurricular activities such as flying teams, student chapters of national organizations (AAAE, Woman in Aviation, alpha eta rho, etc) to you?

10. How satisfied are you with the opportunity to participate in

12345 extracurricular activities at your institution?

\section{Part II}

Using the scales below, please indicate your level of agreement with each of the following statements:

\begin{tabular}{|ccccc|}
\hline Strongly & Somewhat & & Somewhat & Strongly \\
Disagree & Disagree & Agree & Agree & Agree \\
1 & 2 & 3 & 4 & 5 \\
\hline
\end{tabular}

1. Acceptance of transfer credits from another institution is reasonable.

12345

2. Advanced course offerings include internships or senior projects.

12345

3. Billing policies are reasonable.

12345

4. I have learned to adapt to change.

12345

5. Science laboratories are well equipped.

12345

6. Faculty members are scholarly and professionally competent in my major.

12345

7. Class change (drop, add, withdraw) policies are reasonable.

12345

8. If I could start over, I would enroll in this program again.

12345

9. My interpersonal skills have improved as a result of this program.

12345

10. Library resources and services are adequate.

12345

11. Coursework is academically challenging.

12345

12. Computer labs are adequate and accessible.

12345

13. Faculty members come to class well prepared.

12345

14. Content of course material in my major is relevant to the career I am pursuing. 12345 


\begin{tabular}{|ccccc|}
\hline Strongly & Somewhat & & Somewhat & Strongly \\
Disagree & Disagree & Agree & Agree & Agree \\
1 & 2 & 3 & 4 & 5 \\
\hline
\end{tabular}

15. Faculty members are accessible to me outside of class (office hours, email or phone).

12345

16. Tuition paid is a worthwhile investment.

12345

17. This degree is preparing me well for my intended career.

12345

18. The campus facilities and grounds are well maintained.

12345

19. Faculty members are enthusiastic about what they are teaching.

12345

20. Many required courses are only offered sporadically.

12345

21. I often get the "run-around” when seeking information on campus

12345

22. Faculty members are willing to work collaboratively with students

12345 on research efforts

23. This program has done little in developing my critical thinking skills.

12345

24. I would recommend this program to a friend.

12345

25. There are sufficient courses within my major available to me each term.

12345

26. Faculty members provide timely feedback on my academic progress.

12345

27. Office staff (registrar, bursar, financial aid office, department secretary)

12345 are caring and helpful.

28. This program developed my understanding of people from different backgrounds.

12345

29. It is enjoyable being a student in this program.

12345

30. This program has developed my ability to learn independently.

12345

31. Classroom space is adequate.

12345

32. Upper level courses build on knowledge obtained in earlier courses.

12345

33. I am satisfied with my experiences here.

12345

34. Faculty expectations are not made clear to me.

12345 


\begin{tabular}{|ccccc|}
\hline Strongly & Somewhat & & Somewhat & Strongly \\
Disagree & Disagree & Agree & Agree & Agree \\
1 & 2 & 3 & 4 & 5 \\
\hline
\end{tabular}

35. There is a strong sense of community within the department.

12345

36. The program has improved my oral and written communication skills.

12345

37. Enrollment in many of my classes was too high.

12345

38. There is a good variety of courses outside my major available to me each term. 12345

39. I have the opportunity to interact with students from different economic,

12345 social and ethnic backgrounds.

40. Faculty fail to take into account student differences when teaching a course. $\quad \begin{array}{rr}12345\end{array}$

41. My use of technology has improved over the course of this program. $\quad 12345$

42. Instruction in my major field is excellent $\quad 12345$

43. Registering for courses is done efficiently. $\quad 12345$

44. Faculty members are aware of new developments in the field. $\quad 12345$

45. Many required textbooks are not up to date. 12345

46. Students mutually support each other. $\quad 12345$

47. This program developed my ability to function as a member of a group. $\quad 12345$

48. I intend to complete the program I am currently enrolled in at this institution. $\quad \begin{array}{rrr}12345\end{array}$

If you have completed any flight training at your institution, please answer the following:

49. Aircraft are well maintained. $\quad 12345$

50. Aircraft are available to meet students’ needs $\quad 12345$ 
Appendix B

Survey items grouped by variable

\section{Curriculum}

q2: Advanced course offerings include internships or senior projects.

q11: Coursework is academically challenging

q14: Content of course material in my major is relevant to the career I am pursuing.

q25: There are sufficient courses within my major available to me each term.

q32: Upper level courses build on knowledge obtained in earlier courses

q38: There is a good variety of courses outside my major available to me each term

q45: Many required textbooks are not up to date.

\section{Faculty}

q6: Faculty members are scholarly and professionally competent in my major

q13: Faculty members come to class well prepared

q15: Faculty members are accessible to me outside of class (office hours, email or phone)

q19: Faculty members are enthusiastic about what they are teaching

q22: Faculty members are willing to work collaboratively with students on research efforts

q26: Faculty members provide timely feedback on my academic progress

q34: (r) Faculty expectations are not made clear to me

q40: (r) Faculty fail to take into account student differences when teaching a course

q42: Instruction in my major field is excellent

q44: Faculty members are aware of new developments in field

\section{Environment}

q1: Acceptance of transfer credits from another institution is reasonable

q3: Billing policies are reasonable

q7: Class change policies (drop, add, withdraw) are reasonable

q21: (r) I often get the "run-around" when seeking information on campus

q27: Office staff (registrar, bursar, financial aid office, department secretary) are caring and helpful

q35: There is a strong sense of community within the department

q37: (r) Enrollment in many of my classes was too high

q39: I have the opportunity to interact with students from different economic, social and ethnic backgrounds.

q43: Registering for courses is done efficiently

q46: Students mutually support each other

\section{$\underline{\text { Facilities and equipment }}$}

q5: Science laboratories are well equipped

q10: Library resources and services are adequate

q12: Computer labs are adequate and accessible

q18: The campus facilities and grounds are well maintained

q31: Classroom space is adequate

q49: Aircraft are well maintained

q50: Aircraft are available to meet students’ needs 


\section{Student outcomes}

q4: I have learned to adapt to change

q9: My interpersonal skills have improved as a result of this program

q17: This program is preparing me well for my intended career

q23: (r) This program has done little in developing my critical thinking skills

q28: This program developed my understanding of people from different backgrounds

q30: This program has developed my ability to learn independently

q36: The program has improved my oral and written communication skills

q41: My use of technology has improved over the course of this program

q47: This program developed my ability to function as a member of a group

\section{Overall satisfaction}

q8: If I could start over, I would enroll in this program again

q16: Tuition paid is a worthwhile investment

q24: I would recommend this program to a friend

q29: It is enjoyable being a student in this program

q33: I am satisfied with my experiences here.

q48: I intend to complete the program I am currently enrolled in at this institution. 